Tanja Žigon

\title{
Enikö Dácz (ur.): Räumliche Semantisierungen. Raumkonstruktionen in den deutschsprachigen Literaturen aus Zentral- und Südosteuropa im 20.-21. Jahrhundert
}

Regensburg: Friedrich Pustet Verlag, 2018 (Veröffentlichungen des Instituts für deutsche Kultur und Geschichte Südosteuropas an der Ludwig-MaximiliansUniversität München; 135), 287 strani

Lani je v zbirki Inštituta za nemško kulturo in zgodovino jugovzhodne Evrope, ki deluje na Univerzi v Münchnu, izšla obsežna znanstvena monografija, katere naslov bi se v slovenščini glasil Prostorske semantizacije. Koncepti prostora $v$ nemško govorečih književnostih srednje in jugovzhodne Evrope v 20. in 21. stoletju. Uredila jo je znanstvena sodelavka münchenskega inštituta Enikő Dácz in v njej zbrala 16 prispevkov, ki so bili v krajši verziji prvič predstavljeni leta 2015 na mednarodni germanistični konferenci v Braşovu (Romunija). Avtorji in avtorice prispevkov prihajajo iz Nemčije, Hrvaške, Slovenije, Romunije, Madžarske in ZDA.

Že francoski zgodovinar in filozof kulture Michel de Certeau (1925-1986) je prostor (»espace«) za razliko od kraja (»lieu«) razumel kot dinamični pojem, torej kot rezultat prakse, ki poteka na posameznih krajih ter jih spreminja $\mathrm{v}$ prostore individualnega delovanja; tega pa različni akterji različno predstavijo in opišejo, kar je povezano tako z izkustvenimi svetovi posameznikov kakor tudi s kulturnimi in prostorskimi danostmi. Prostor v književnih besedilih torej ni le kraj dogajanja, temveč v sebi skriva tudi pomen, kot sta pred dobrim desetletjem v monografiji o pojmu prostora in gibanja $\mathrm{v}$ književnosti zapisala Wolfgang Hallet in Birgit Neumann (Raum und Bewegung in der Literatur. Die Literaturwissenschaften und der Spatial Turn, Bielefeld: transcript Verlag 2009). Nekaj let pozneje smo znanstveno monografijo o prostorskem obratu (t. i. spatial turn) v literarni vedi, ki so jo uredili Marko Juvan, Marijan Dović in Jernej Habjan, dobili tudi v slovenskem prostoru (Ljubljana: Slovensko društvo za primerjalno književnost 2013). Tudi v tem delu so se prispevki osredotočali na vprašanja, kot so kaj prostorski obrat prinaša literarni vedi, v kakšnem razmerju je prostorska epistemologija s časovnostjo in pripovednostjo, na katerih je utemeljena literarna veda, kaj je literarna geografija in podobno. 
Tudi pričujoča monografija, ki so jo pripravili münchenski kolegi, izhaja iz prostorskega (topografskega/topološkega) obrata, ki v zadnjih desetletjih v teoretskih razpravah $\mathrm{v}$ ospredje kulturoloških in literarnoznanstvenih raziskav postavlja ne le »čas«, temveč tudi "prostor« oziroma geografski prostor in prostorske kontekste. Monografija obravnava poetizacijo prostora $\mathrm{v}$ književnosti srednje in jugovzhodne Evrope 20. in 21. stoletja, preučuje tekstualni prostor izbranih literarnih besedil in se sprašuje o topografskih posebnostih nemško govorečih literatur obravnavanega geografskega prostora. $\mathrm{V}$ ospredju so razmišljanja o fikciji prostora, pri čemer je posebna pozornost posvečena fiktivnim in realnim prostorskim danostim, sledijo pa semiotične analize jezikovno-prostorskih odnosov, ki se kažejo med posameznimi liki, med liki in predmeti ter v odnosu do izvenjezikovne resničnosti. Med temeljne tematske poudarke $\mathrm{v}$ monografiji sodijo strategije vizualizacije in prostorskega obrata, uprizarjanje menjave prostora, heterotopični prostorski koncepti, prostorske upodobitve srečevanj različnih kultur, koncepti identitete in alteritete, fikcijski modeli resničnosti perifernih prostorov ter upodobitve prostora, ko gre za procese spominjanja oziroma za pokrajine spomina. V središču so torej različni vidiki prostora $\mathrm{v}$ književnih besedilih, med njimi topografsko-geografski, retorični, zaznavni in narativni, prispevki pa obravnavajo na eni strani tako imenovane »regionalne književnosti«, na drugi pa dela avtoric in avtorjev, ki so v Nemčijo prišli iz srednje in jugovzhodne Evrope ter pišejo v nemščini.

Uvodni prispevek izpod peresa Magdolne Orosz (»Raum « und »Raumdarstellung« als Kategorien literarischer (narrativer) Textanalyse) prinaša jasen in zgoščen pregled kulturoloških in literarnovednih teorij prostora ter predstavi dosedanje raziskave, obenem pa na podlagi študij primerov, ki se nanašajo na čas in prostor Avstro-Ogrske ob izbruhu prve svetovne vojne, predstavi regionalno specifične koncepte prostora ter historične reference, potrebne za razumevanje besedil in razmerij med geografskimi in fikcijskimi svetovi. Tu opisane skupne značilnosti prostorskih narativov se kažejo tudi v obeh tematskih sklopih oziroma poglavjih monografije. Razprave v prvem poglavju (Fiktionale Räume) se osredotočajo na fikcijske prostore, v drugem poglavju (Rauminszenierungen in medialen Kontexten) pa so zbrani prispevki, ki se osredinjajo na inscenacije prostora $\mathrm{v}$ medialnih kontekstih, torej $\mathrm{v}$ esejih, avtobiografijah, spominih, časopisih in korespondencah.

V prvem sklopu je zbranih sedem prispevkov. Enikő Dácz v svoji razpravi, upoštevajoč naratološka in kulturološka teoretična izhodišča, proučuje literarna prizorišča in prostore v romanu Zwischen Grenzen und Zeiten Heinricha Zillicha (1898-1988), ki sicer zaradi svojih kulturno-političnih pogledov in simpatiziranja $z$ nacionalsocializmom velja za kontroverznega avtorja. Avtorica roman analizira na podlagi tristopenjskega modela mimesis, ki ga je utemeljil Paul Ricœur, ter v ospredje 
postavi vprašanje, v kolikšni meri Zillichov ideološko obarvani roman performativno (so)oblikuje prostor, o katerem piše, torej Sedmograško med prvo svetovno vojno in neposredno po njej. V naslednjem prispevku germanistke in romunistke Laure Laza je v središču literarna zapuščina sedmograškega lirika Wolfa von Aichelburga (1912-1994), shranjena $\mathrm{v}$ romunskem državnem arhivu, kjer so $\mathrm{v}$ študijske in raziskovalne namene dostopni akti državne varnostne službe Securitate. V Pulju rojeni Aichelburg, ki je konec prve svetovne vojne s starši prišel v romunski Sibiu, kjer se je družina ustalila, se je namreč konec petdesetih let prejšnjega stoletja znašel pod drobnogledom romunske varnostne službe. Sumljiv je postal, ker je v letih 1928-1934 študiral germanistiko in romanistiko, a ne le v Romuniji (Cluj-Napoca), temveč tudi v Franciji (Dijon). Leta 1939 se je vrnil na Sedmograško, leta 1959 pa je bil na procesu proti nemški skupini pisateljev pred sodiščem v Braşovu obsojen na 25 let zapora. Njegove pesmi, nastale v romunskih zaporih in delovnih taboriščih, do danes še niso objavljene, zato je prispevek Laure Laza toliko bolj dragocen. V njem se avtorica posveča vprašanju razmerja med fikcijskim in realnim svetom v Aichelburgovi liriki, predvsem temu, kje prostorska imaginarnost tako rekoč prekrije realni prostor. Podobno je tudi izhodišče Raluce Cernahoschi, ki v svojem prispevku analizira realne in imaginarne topografije v pesnitvi Horsta Samsona (roj. 1954) La Victoire. Čeprav je dogajanje v vseh 52 pesmih, ki sestavljajo pesnitev, postavljeno v romunsko okolje, avtorica ugotavlja, da kljub temu ne moremo govoriti o enem samem in enotnem prostoru, ki bi mu rekli »Romunija«. R. Cernahoschi zato analizira razmerje med izkustvenim in literarnim prostorom ter sklene, da gre za literarno topografijo, v kateri se geografski prostori spreminjajo v zelo različne (tekstualne) prostore. Predstavljeni so prostori tranzita, moči in nasprotij, med njimi apokaliptični prostori v času vojne ali pa kraji deportacij in izseljevanja romunskih Nemcev v času komunističnega režima, pri čemer se avtorica posveča predvsem vprašanju, ali pesmi lahko ustvarijo literarni medkontekstualni prostor kot strategijo osvoboditve banatskih Nemcev. Prav to pa je osrednja tema naslednje razprave, ki sta jo prispevali Roxana Nubert in Ana-Maria Dascălu-Romițan, v kateri Banat obravnavata kot kraj spomina v pesmih romunskonemškega lirika in pripovednika Johanna Lippeta (roj. 1951). Lippet v svojih verzih in prozi išče izgubljeni čas in izgubljeno deželo. Oriše fikcijske scenarije propada banatskih Nemcev ter premišljuje o osebnih in historičnih procesih, ki so potekali pred njegovimi očmi, pri čemer se zgodbe in usode posameznih družin stapljajo v eno samo zgodbo skupnosti. V nadaljevanju madžarska komparativistka Eszter Propszt analizira razmerje med dojemanjem prostora in identiteto v romanu Béla Bayerja (roj. 1951), v katerem je madžarsko-nemška zgodovina predstavljena kot model prostora. Analiza temelji na semiotičnem konceptu prostora Jurija Lotmana in odgovarja na vprašanje, kakšna identifikacija z modelom prostora je na voljo bralcu ter ali in kako jo lahko uporabimo za interpretacijo vsakodnevnih in zgodovinskih izkušenj madžarskih 
Nemcev. Zadnja prispevka prvega poglavja monografije obravnavata specifične tematike, ki se pojavljajo $\mathrm{v}$ delih avtorjev in avtoric $\mathrm{z}$ migracijskim ozadjem, predvsem pa se ukvarjata $\mathrm{z}$ njihovo umestitvijo med jezike in prostore. Raluca Rădulescu se ukvarja z literarnim opusom Dragice Rajčić (roj. 1959), ki prihaja iz Hrvaške in je v času zadnje vojne v Jugoslaviji z otroki zbežala v Švico. R. Rădulescu v svojem prispevku, izhajajoč iz teoretičnih premis M. Foucaulta, M. Augéja in J. Habermasa, predstavi večplastno identitetno umeščenost besedil Dragice Rajčić, kar interpretira kot poetiko prostora in ugotavlja, da je domovina za pisateljico pravzaprav le kraj, ki ga ni, prostor, ki ne pozna meje med realnostjo in domišljijo. S podobno tematiko se bralec sreča tudi v prispevku Réke Sánta-Jakabházi: v analiziranem romanu Aglaye Veteranyi (1962-2002), ki se osredotoča na družino umetnikov, ki so pobegnili iz Romunije, je cirkus namreč predstavljen kot heterotopični prostor.

Drugi del monografije, ki je posvečen inscenacijam prostora $\mathrm{v}$ medialnih kontekstih, prinaša osem razprav. $\mathrm{V}$ prvem prispevku romunsko-nemški germanist Szabolcs János razpravlja o regionalnih kulturah Transilvanije in Banata v potopisih 18. in 19. stoletja, pri čemer sta $\mathrm{v}$ ospredju tako koncept prostora kakor tudi problematično vprašanje tako imenovane »regionalne literature« in njene vloge pri nastanku »regionalnih identitet«. V naslednjem prispevku se Olivia Spiridon naveže na predhodne Jánoseve ugotovitve in razloži vidik meje v banatski občini Hatzfeld v 20. stoletju. Obmejni pas, naselitveno območje in življenjski prostor Nemcev v Romuniji prikaže kot prostor konfliktov in eskalacij, pa tudi kompromisov, saj prihaja do živahne izmenjave med kulturama in inovativnih prestopov meje. Medtem ko Spiridon in Dácz (v prvem sklopu monografije) obravnavata razmerje med prostorskimi in ideološkimi vidiki, se naslednji prispevek izpod peresa Michaele Nowotnick osredotoča na literarne interakcije med prostori $\mathrm{v}$ geografskem smislu, in sicer med Transilvanijo in Nemčijo; literarna prepletanja avtorica podrobno pojasni in interpretira na primeru revije Ostland ter njenega urednika in izdajatelja Richarda Csakija. Sledijo tri razprave, ki se ukvarjajo z Bukovino. Ana-Maria Pălimariu v svojem prispevku analizira avtobiografijo psihiatra in psihoanalitika Wilhelma Reicha (1897-1957) ter razpravlja o imaginarni podobi Judov iz Bukovine v njegovem besedilu. Uveljavljeni romunski germanist George Guțu predstavi dopisovanje Alfreda Margula-Sperberja (1898-1967) z bukovinskimi avtorji (Moses Rosenkranz, Rose Ausländer in Paul Celan) ter na osnovi pregledanih korespondenc oriše propad mita o Bukovini z vsemi njegovimi posledicami; prostor se tu zdi kot insceniran, kot kulisa, ki je potrebna zato, da se ohrani poetična identiteta protagonistov. Tretji prispevek, ki obravnava isto geografsko območje, pa se ukvarja z zbirko kratkih zgodb Edgarja Hilsenratha (roj. 1926) Sie trommelten mit den Fäusten den Takt [S pestmi so bobnali takt]. Francisca Solomon tu proučuje Bukovino in Transnistrijo kot pokrajini spomina in katastrofe, 
pri čemer upošteva teoretična raziskovanja o krajih spomina Aleide Assmann in teorijo mehanizmov oblikovanja judovske identitete, ki jo je utemeljil James Young. V središču zadnjih dveh prispevkov je južnoslovanski prostor. Zagrebška germanistka Milka Car v svojem prispevku tematizira prepletanje politične ideologije in literarne predstave prostora na primeru znanega eseja Illyricum sacrum Miroslava Krleže (18931981), ki je bil najprej napisan v hrvaščini in šele kasneje preveden v nemščino. V tem smislu smemo monografijo razumeti tudi kot izhodišče za nadaljnje medkulturne, prevodoslovne in interdisciplinarne analize. $\mathrm{V}$ zadnjem prispevku germanistka in komparativistka Irena Samide (Ljubljana) obravnava življenjske, literarne, genderske in geobiografske prostore $\mathrm{v}$ potopisih izjemne avtorice, popotnice in svetovljanke Alme M. Karlin (1889-1950), ki v enem od svojih del pravi, da v življenju ne smemo misliti le nase, temveč se moramo prilagajati in vse obrniti sebi v prid, kajti le takšnemu človeku bo »življenje cvetoča livada in še po smrti ostanejo za njim sledovi njegovih del « (Alma M. Karlin: Pod košatim očesom. Celje: Mohorjeva družba 2002, str. 51).

Monografija prinaša širok spekter različnih tem s področja literarnovednih in kulturoloških študij. Tematska raznolikost prispevkov na eni strani ponuja vpogled $\mathrm{v}$ stanje na področju raziskovanja zaznavanja prostora in prostorskega mišljenja $\mathrm{v}$ književnosti, na drugi strani pa odgovarja na številna vprašanja, povezana $\mathrm{z}$ »literarnim prostorom « in "prostori literature«, ter hkrati odpira prostor za nove raziskave. Delo odlikujeta metodološka in tematska prepričljivost prispevkov, za katere so značilni analitična ostrina, razumljiva in prepričljiva znanstvena argumentacija in kritično uravnoteženi zaključki, ki temeljijo na empiričnih ter transparentnih utemeljitvah. Znanstvena monografija, kjer pogrešamo le stvarno in imensko kazalo, ki bi bila primerno dopolnilo knjigi, bo zagotovo dobrodošlo branje za raziskovalce in strokovnjake s področja literarnih in sorodnih ved, prav tako pa jo bodo $\mathrm{v}$ roke $\mathrm{z}$ veseljem vzeli študenti, učitelji in laična javnost, ki razume in bere nemško. 